\title{
Marmoricola korecus sp. nov.
}

Correspondence
Soon Dong Lee
sdlee@jejunu.ac.kr

\section{Soon Dong Lee, ${ }^{1,2}$ Dong Wan Lee ${ }^{1 \dagger}$ and Young-Hwan $\mathrm{Ko}^{3}$}

\author{
${ }^{1}$ Department of Science Education, Jeju National University, Jeju 690-756, Republic of Korea \\ ${ }^{2}$ Educational Science Research Institute, Jeju National University, Jeju 690-756, Republic of Korea \\ ${ }^{3}$ Department of Food Science and Engineering, Jeju National University, Jeju 690-756, Republic of \\ Korea
}

\begin{abstract}
A novel actinomycete, designated strain Sco- $\mathrm{A36}^{\top}$, was isolated from volcanic ash. Cells were aerobic, Gram-stain-positive, oxidase-negative, catalase-positive, non-motile cocci; colonies were yellow-coloured, smooth, entire and convex. Phylogenetic analysis showed that the organism formed a distinct phyletic line within the radiation of the genus Marmoricola. Its closest phylogenetic neighbours were Marmoricola aurantiacus DSM $12652^{\top}$ (97.9\% 16S rRNA gene sequence similarity), Marmoricola scoriae Sco-D01 ${ }^{\top}$ (97.9\%), Marmoricola aequoreus SST-45 ${ }^{\top}$ $(97.4 \%)$ and Marmoricola bigeumensis MSL-05 ${ }^{\top}$ (96.3\%). The diagnostic diamino acid in the cell walls was LL-diaminopimelic acid. The predominant menaquinone was MK- $8\left(\mathrm{H}_{4}\right)$. The polar lipids contained phosphatidylinositol, diphosphatidylglycerol, phosphatidylglycerol, phosphatidylcholine and an unknown phospholipid. The predominant fatty acids were $\mathrm{C}_{16: 0 \text {, }}$ $\mathrm{C}_{17: 1} \omega 8 c, \mathrm{C}_{18: 1} \omega 9 c$ and $\mathrm{C}_{16: 1} \omega 7 c$ and/or iso- $\mathrm{C}_{15: 0} 2-\mathrm{OH}$. The DNA G+C content of strain Sco-A36 ${ }^{\top}$ was 71.0 mol\%. Levels of DNA-DNA relatedness between the new isolate and the type strains of recognized species of the genus Marmoricola were 4.9-29.2\%. The phenotypic and DNA-DNA hybridization data presented here strongly suggest that strain Sco-A36 ${ }^{\top}$ represents a novel species of the genus Marmoricola, for which the name Marmoricola korecus sp. nov. is proposed. The type strain is Sco-A36 ${ }^{\top}\left(=\operatorname{KCTC}_{19596^{\top}}=\mathrm{DSM} 22128^{\top}\right)$.
\end{abstract}

The genus Marmoricola was proposed by Urzì et al. (2000), with the description of Marmoricola aurantiacus as the type and only species. Subsequently, Marmoricola aequoreus (Lee, 2007), Marmoricola bigeumensis (Dastager et al., 2008) and Marmoricola scoriae (Lee \& Lee, 2010) have been described. These bacteria form a phylogenetically coherent cluster within the family Nocardioidaceae and are well separated from other genera of the family (Lee \& Lee, 2010). Members of the genus have been isolated from marble, beach sediment, agricultural soil and volcanic ash. In the present study, we describe the identification and classification of a Marmoricola strain isolated from scoria, designated Sco-A $36^{\mathrm{T}}$, based on a polyphasic taxonomic approach.

Strain Sco-A36 ${ }^{\mathrm{T}}$ was isolated from a red layer of scoria (volcanic ash) collected in Jeju, Republic of Korea. Treatment of the volcanic ash sample and preparation of media for bacterial isolation were performed as described

tPresent address: Division of Bioscience and Technology, College of Life and Environmental Sciences, Korea University, Seoul 136-713, Republic of Korea.

The GenBank/EMBL/DDBJ accession number for the 16S rRNA gene sequence of strain Sco-A36 ${ }^{\top}$ is FN386723.

A supplementary figure and table are available with the online version of this paper. by Lee $\&$ Lee (2010). The pure culture was maintained in a $20 \%(\mathrm{v} / \mathrm{v})$ glycerol solution at -20 and $-80{ }^{\circ} \mathrm{C}$. For DNA-DNA hybridization experiments, $M$. aequoreus SST$45^{\mathrm{T}}$, M. aurantiacus DSM $12652^{\mathrm{T}}$ and M. scoriae Sco-D01 ${ }^{\mathrm{T}}$ were used as reference strains.

Cell biomass for DNA extraction and chemotaxonomic characterization was obtained from cultures grown in International Streptomyces Project medium 2 (ISP 2) broth [0.4\% glucose, $1.0 \%$ malt extract and $0.4 \%$ yeast extract, pH 7.2 (Shirling \& Gottlieb, 1966)] at $30{ }^{\circ} \mathrm{C}$. Chromosomal DNA was extracted and purified by using a Wizard Genomic DNA Purification kit (Promega) according to the manufacturer's instructions. Amplification and sequencing of the 16S rRNA gene and phylogenetic analyses were performed as described by Lee \& Lee (2008).

A partial 16S rRNA gene sequence (1426 nt) of strain Sco$\mathrm{A} 36^{\mathrm{T}}$ was determined in this study and was aligned with those of members of the genus Marmoricola and related taxa. A neighbour-joining tree (Fig. 1) based on $16 \mathrm{~S}$ rRNA gene sequence analyses revealed that strain $\mathrm{Sco}-\mathrm{A} 36^{\mathrm{T}}$ belonged to the genus Marmoricola and formed a distinct phyletic line between a cluster comprising $M$. scoriae $-M$. aurantiacus and $M$. aequoreus. This relationship was supported by a bootstrap value of $97 \%$ and was also found in trees generated by the maximum-parsimony and 


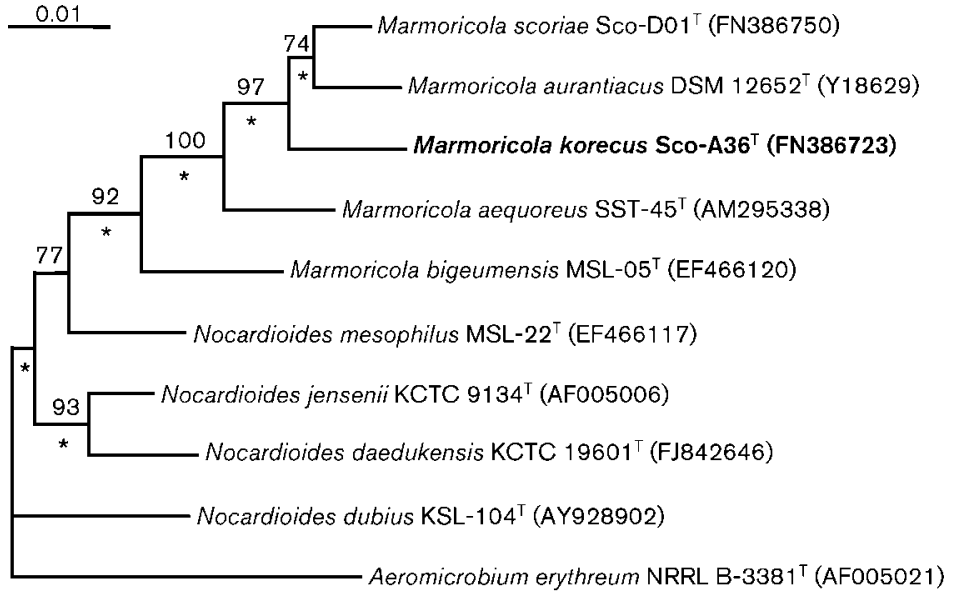

Fig. 1. Phylogenetic tree based on $16 \mathrm{~S}$ rRNA gene sequences showing the position of strain $\mathrm{S} c 0-\mathrm{A} 36^{\top}$ within the radiation occupied by the genus Marmoricola. The tree was constructed by using the model of Jukes \& Cantor (1969) and the neighbour-joining method (Saitou \& Nei, 1987). Aeromicrobium erythreum NRRL $\mathrm{B}-3381^{\top}$ was used as an outgroup. Asterisks indicate branches that were also found in the maximum-likelihood (Fitch, 1971) and maximum-parsimony (Felsenstein, 1981) trees. Bootstrap values are shown at branch points based on 1000 resamplings. Bar, 0.01 substitutions per nucleotide position.

maximum-likelihood methods. Levels of 16S rRNA gene sequence similarity between strain Sco-A $36^{\mathrm{T}}$ and $M$. aurantiacus DSM $12652^{\mathrm{T}}, M$. scoriae Sco-D01 ${ }^{\mathrm{T}}, M$. aequoreus SST- $45^{\mathrm{T}}$ and $M$. bigeumensis $\mathrm{MSL}-05^{\mathrm{T}}$ were 97.9, 97.9, 97.4 and $96.3 \%$, respectively. Strain Sco-A36 ${ }^{\mathrm{T}}$ shared low levels of $16 \mathrm{~S}$ rRNA gene sequence similarity $(<95 \%)$ with the type strains of related species of the genus Nocardioides.

The isomer of diaminopimelic acid in the cell-wall peptidoglycan (Staneck \& Roberts, 1974), major menaquinones (Kroppenstedt, 1985), polar lipids (Minnikin et al., 1977), G + C content of the DNA (Mesbah et al., 1989) and cellular fatty acids were analysed as described by Lee \& Lee (2010). For fatty acid analysis, strain Sco-A $36^{\mathrm{T}}$ was grown on R2A agar for 5 days at $30{ }^{\circ} \mathrm{C}$.

The diagnostic diamino acid in the cell-wall peptidoglycan of strain Sco-A36 ${ }^{\mathrm{T}}$ was LL-diaminopimelic acid. The predominant menaquinone was $\mathrm{MK}-8\left(\mathrm{H}_{4}\right)$. The polar lipids contained phosphatidylinositol, diphosphatidylglycerol, phosphatidylglycerol, phosphatidylcholine and an unknown phospholipid. Phosphatidylcholine is also found in M. scoriae, but not in M. aequoreus, M. aurantiacus or M. bigeumensis. The fatty acid profile of strain Sco-A $36^{\mathrm{T}}$ contained saturated, unsaturated, 10-methyl and hydroxyl components, with the major fatty acids being $\mathrm{C}_{16: 0}, \mathrm{C}_{17: 1} \omega 8 c, \mathrm{C}_{18: 1} \omega 9 c$, and $\mathrm{C}_{16: 1} \omega 7 c$ and/or iso- $\mathrm{C}_{15: 0} 2-\mathrm{OH}$. The detailed cellular fatty acid profiles of strain Sco-A $36^{\mathrm{T}}$ and the type strains of recognized species of the genus Marmoricola are given in Supplementary Table S1 in IJSEM Online. The DNA G + C content of strain Sco-A36 ${ }^{\mathrm{T}}$ was $71.0 \mathrm{~mol} \%$.

Tests for morphological, cultural, physiological and biochemical properties were performed as described by Lee \& Lee (2010). Cells of strain Sco-A36 ${ }^{\mathrm{T}}$ were aerobic, Gram-positive, oxidase-negative, catalase-positive, nonmotile cocci (1.1-1.2 $\mu \mathrm{m}$ in diameter; see Supplementary Fig. S1). Colonies were yellow, circular and convex with entire margins. Data for other physiological and biochemical features are given in Table 1 and in the species description below.
Morphological and cultural characteristics of strain Sco-A36 ${ }^{\mathrm{T}}$ were similar to those of the type strain of $M$. scoriae (Lee \& Lee, 2010), although the two were isolated from different sources of scoria; strain Sco-A36 ${ }^{\mathrm{T}}$ was isolated from a red layer of a volcanic ash, whereas $M$. scoriae $\mathrm{Sco}-\mathrm{D} 01^{\mathrm{T}}$ was isolated from a yellow-brown layer. The two strains could be differentiated from each other based on temperature and $\mathrm{pH}$ ranges for growth and, in particular, based on utilization of carbohydrates. Differential characteristics between strain Sco-A $36^{\mathrm{T}}$ and the type strains of recognized species of the genus Marmoricola are given in Table 1 .

DNA-DNA hybridization was carried out by using the method of Ezaki et al. (1989); levels of DNA-DNA relatedness were determined fluorometrically as described by Yoon et al. (2007). Levels of DNA-DNA relatedness between Sco-A36 ${ }^{\mathrm{T}}$ and the type strains of recognized species of the genus Marmoricola were 4.9-29.2\% (SD, $12.2 \%$, five replications), showing that strain Sco-A36 ${ }^{\mathrm{T}}$ represents a distinct genomic species (Wayne et al., 1987).

On the basis of the data presented here, we suggest that strain Sco-A36 ${ }^{\mathrm{T}}$ represents a novel species of the genus Marmoricola, for which the name Marmoricola korecus sp. nov. is proposed.

\section{Description of Marmoricola korecus sp. nov.}

Marmoricola korecus (ko.re'cus. N.L. masc. adj. korecus pertaining to Korea, from where the type strain was isolated).

Cells are aerobic, Gram-positive, oxidase-negative, catalase-positive, non-motile cocci. Colonies are yellow, circular and convex with entire margins. Growth occurs at $\mathrm{pH}$ 5.1-12.1 (optimum, $\mathrm{pH} 6.1-10.1$ ), at $4-37^{\circ} \mathrm{C}$ (optimum, $30{ }^{\circ} \mathrm{C}$ ) and in the presence of up to $2 \%$ $(\mathrm{w} / \mathrm{v}) \mathrm{NaCl}$. Aesculin is hydrolysed, but CM-cellulose, hypoxanthine, DL-tyrosine and xanthine are not. Nitrate is not reduced to nitrite. Gelatin liquefaction is observed. Positive in tests for alkaline phosphatase, esterase lipase (C8), leucine arylamidase, valine arylamidase, cystine 
Table 1. Differential characteristics between strain $\mathrm{Sco}-\mathrm{A} 36^{\top}$ and the type strains of recognized species of the genus Marmoricola

Strains: 1, Sco-A36 ${ }^{\mathrm{T}}$; 2, M. aequoreus SST-45 ${ }^{\mathrm{T}}$ (data from Lee, 2007); 3, M. aurantiacus DSM 12652 ${ }^{\mathrm{T}}$ (Urzì et al., 2000; Lee \& Lee, 2010); 4, M. bigeumensis MSL-05 ${ }^{\mathrm{T}}$ (Dastager et al., 2008; Lee \& Lee, 2010); 5, M. scoriae Sco-D01 ${ }^{\mathrm{T}}$ (Lee \& Lee, 2010). All of the strains were aerobic, Grampositive, oxidase-negative, catalase-positive and positive for aesculin hydrolysis. All were positive for alkaline phosphatase, esterase lipase (C8), leucine arylamidase, $\alpha$-glucosidase, $\beta$-glucosidase and the Voges-Proskauer reaction but negative for lipase (C14), $\alpha$-galactosidase, $\beta$-glucuronidase, $N$-acetyl- $\beta$-glucosaminidase, $\alpha$-mannosidase, $\alpha$-fucosidase, arginine dihydrolase, lysine decarboxylase, ornithine decarboxylase, urease, tryptophan deaminase and indole production (API ZYM and API 20E strips). All of the strains utilized glucose, D-mannitol and methyl $\alpha$-D-glucoside as sole carbon source but not formate, meso-inositol, methyl $\alpha$-D-mannoside or L-sorbose. +, Positive; -, negative; w, weakly positive; ND, not determined.

\begin{tabular}{|c|c|c|c|c|c|}
\hline Characteristic & 1 & 2 & 3 & 4 & 5 \\
\hline Colony colour & Yellow & Yellow & Orange & Lemon yellow & Vivid yellow \\
\hline Cell motility & - & - & - & + & - \\
\hline Temperature range for growth $\left({ }^{\circ} \mathrm{C}\right)$ & $4-37$ & $10-37$ & $18-28$ & $20-37$ & $10-37$ \\
\hline $\mathrm{pH}$ range for growth & $5.1-12.1$ & $5.1-12.1$ & $5.1-8.7$ & $6.0-12.0$ & $6.1-12.1$ \\
\hline $\mathrm{NaCl}$ concentration for growth (\%) & $0-2.0$ & $0-7.0$ & $0.5-2.0$ & $0-7.0$ & $0-3.0$ \\
\hline Nitrate reduction & - & + & - & + & - \\
\hline$\beta$-Galactosidase & - & + & $\mathrm{w}$ & + & + \\
\hline \multicolumn{6}{|l|}{ Degradation of: } \\
\hline Casein & + & + & - & - & + \\
\hline DNA & - & ND & - & - & + \\
\hline Gelatin & + & + & - & - & + \\
\hline Starch & - & - & - & + & - \\
\hline \multicolumn{6}{|l|}{ Enzyme activities } \\
\hline Acid phosphatase & + & - & + & + & + \\
\hline$\alpha$-Chymotrypsin & - & - & - & + & - \\
\hline Cystine arylamidase & $\mathrm{W}$ & $\mathrm{W}$ & - & + & $\mathrm{W}$ \\
\hline Esterase (C4) & - & - & $\mathrm{w}$ & + & - \\
\hline $\begin{array}{l}\text { Naphthol-AS-BI- } \\
\text { phosphohydrolase }\end{array}$ & + & - & + & + & + \\
\hline Trypsin & $\mathrm{W}$ & - & - & + & $\mathrm{W}$ \\
\hline Valine arylamidase & + & + & $\mathrm{w}$ & - & + \\
\hline \multicolumn{6}{|l|}{ Utilization of: } \\
\hline Acetate & - & + & + & + & + \\
\hline Adonitol & + & - & + & - & - \\
\hline D-Arabinose & - & - & + & - & + \\
\hline Cellobiose & + & + & + & + & - \\
\hline Citrate & - & + & + & - & + \\
\hline Dextran & - & + & + & + & - \\
\hline Dulcitol & + & - & - & - & - \\
\hline D-Fructose & - & + & + & - & + \\
\hline D-Galactose & - & + & + & - & + \\
\hline Glycerol & - & + & + & - & - \\
\hline Lactose & - & + & + & + & - \\
\hline DL-Malate & - & + & + & - & + \\
\hline Maltose & - & + & + & + & + \\
\hline D-Mannose & + & + & + & + & - \\
\hline Melezitose & - & + & + & - & + \\
\hline meso-Erythritol & + & - & - & - & - \\
\hline Raffinose & - & - & + & - & + \\
\hline L-Rhamnose & - & - & + & + & + \\
\hline L-Ribose & - & + & + & - & + \\
\hline Salicin & - & - & + & - & + \\
\hline D-Sorbitol & - & + & + & + & - \\
\hline Succinate & + & + & + & - & - \\
\hline Sucrose & - & + & + & - & + \\
\hline DL-Tartrate & - & - & + & - & - \\
\hline Trehalose & - & + & + & - & + \\
\hline
\end{tabular}


Table 1. cont.

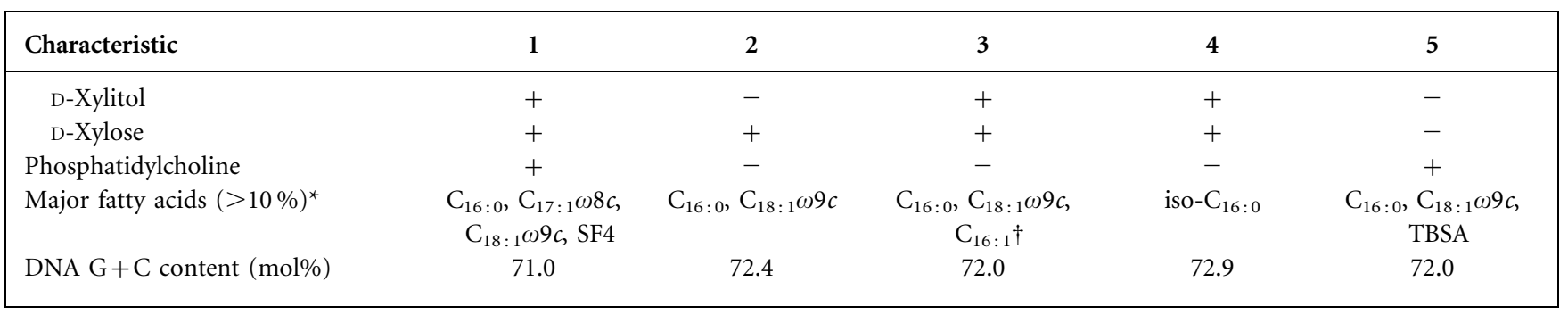

${ }^{*} \mathrm{SF} 4, \mathrm{C}_{16: 1} \omega 7 c$ and/or iso- $\mathrm{C}_{15: 0}$ 2-OH; TBSA, tuberculostearic acid.

$\dagger$ Present as a main component in a previous report (Urzì et al., 2000), but not detected in our study (Lee \& Lee, 2010).

arylamidase (weak response), trypsin (weak response), acid phosphatase, naphthol-AS-BI-phosphohydrolase, $\alpha$-glucosidase, $\beta$-glucosidase (API ZYM) and the Voges-Proskauer reaction (API 20E). Utilizes adonitol, cellobiose, mesoerythritol, D-glucose, D-mannitol, D-mannose, methyl $\alpha$-Dglucoside, succinate, D-xylitol and D-xylose as sole carbon and energy sources. Data for other physiological properties are given in Table 1. The polar lipids include phosphatidylinositol, diphosphatidylglycerol, phosphatidylglycerol, phosphatidylcholine and an unknown phospholipid. The major fatty acids are $\mathrm{C}_{16: 0}, \mathrm{C}_{17: 1} \omega 8 c, \mathrm{C}_{18: 1} \omega 9 c$ and $\mathrm{C}_{16: 1} \omega 7 c$ and/or iso- $\mathrm{C}_{15: 0} 2-\mathrm{OH}$.

The type strain, Sco-A $36^{\mathrm{T}} \quad\left(=\right.$ KCTC $19596^{\mathrm{T}}=\mathrm{DSM}$ $22128^{\mathrm{T}}$ ), was isolated from scoria (volcanic ash) in Jeju, Republic of Korea. The G+C content of the DNA of the type strain is $71.0 \mathrm{~mol} \%$.

\section{Acknowledgements}

This work was supported by the 21C Frontier Microbial Genomics and Application Center Program, Ministry of Science \& Technology, Republic of Korea.

\section{References}

Dastager, S. G., Lee, J.-C., Ju, Y.-J., Park, D.-J. \& Kim, C.-J. (2008). Marmoricola bigeumensis sp. nov., a member of the family Nocardioidaceae. Int J Syst Evol Microbiol 58, 1060-1063.

Ezaki, T., Hashimoto, Y. \& Yabuuchi, E. (1989). Fluorometric deoxyribonucleic acid-deoxyribonucleic acid hybridization in microdilution wells as an alternative to membrane filter hybridization in which radioisotopes are used to determine genetic relatedness among bacterial strains. Int J Syst Bacteriol 39, 224-229.

Felsenstein, J. (1981). Evolutionary trees from DNA sequences: a maximum likelihood approach. J Mol Evol 17, 368-376.

Fitch, W. M. (1971). Towards defining the course of course of evolution: minimum change for a specific tree topology. Syst Zool 20, 406-416.
Jukes, T. H. \& Cantor, C. R. (1969). Evolution of protein molecules. In Mammalian Protein Metabolism, pp. 21-132. Edited by H. N. Munro. New York: Academic Press.

Kroppenstedt, R. M. (1985). Fatty acid and menaquinone analysis of actinomycetes and related organisms. In Chemical Methods in Bacterial Systematics, pp. 173-199. Edited by M. Goodfellow \& D. E. Minnikin. London: Academic Press

Lee, S. D. (2007). Marmoricola aequoreus sp. nov., a novel actinobacterium isolated from marine sediment. Int $J$ Syst Evol Microbiol 57, 1391-1395.

Lee, D. W. \& Lee, S. D. (2008). Aeromicrobium ponti sp. nov., isolated from seawater. Int J Syst Evol Microbiol 58, 987-991.

Lee, D. W. \& Lee, S. D. (2010). Marmoricola scoriae sp. nov., isolated from volcanic ash. Int J Syst Evol Microbiol 60, 2135-2139.

Mesbah, M., Premachandran, U. \& Whitman, W. B. (1989). Precise measurement of the $\mathrm{G}+\mathrm{C}$ content of deoxyribonucleic acid by highperformance liquid chromatography. Int J Syst Bacteriol 39, 159-167.

Minnikin, D. E., Alshamaony, L. \& Goodfellow, M. (1977). Differentiation of Mycobacterium, Nocardia, and related taxa by thin layer chromatographic analysis of whole-cell methanolysates. J Gen Microbiol 88, 200-204.

Saitou, N. \& Nei, M. (1987). The neighbor-joining method: a new method for reconstructing phylogenetic trees. Mol Biol Evol 4, 406-425.

Shirling, E. B. \& Gottlieb, D. (1966). Methods for characterization of Streptomyces species. Int J Syst Bacteriol 16, 313-340.

Staneck, J. L. \& Roberts, G. D. (1974). Simplified approach to identification of aerobic actinomycetes by thin-layer chromatography. Appl Microbiol 28, 226-231.

Urzì, C., Salamone, P., Schumann, P. \& Stackebrandt, E. (2000). Marmoricola aurantiacus gen. nov., sp. nov., a coccoid member of the family Nocardioidaceae isolated from a marble statue. Int J Syst Evol Microbiol 50, 529-536.

Wayne, L. G., Brenner, D. J., Colwell, R. R., Grimont, P. A. D., Kandler, O., Krichevsky, M. I., Moore, L. H., Moore, W. E. C., Murray, R. G. E. \& other authors (1987). Report of the ad hoc committee on reconciliation of approaches to bacterial systematics. Int J Syst Bacteriol 37, 463-464.

Yoon, J.-H., Kang, S.-J., Lee, S.-Y. \& Oh, T.-K. (2007). Loktanella maricola sp. nov., isolated from seawater of the East Sea in Korea. Int $J$ Syst Evol Microbiol 57, 1799-1802. 